\section{Boron-Catalyzed N-Alkylation of Amines Using Carboxylic Acids}

\section{Gategory}

Synthesis of Natural

Products and

Potential Drugs

\section{Key words}

\section{Cinacalcet}

Butenafine

Piribedil

N-alkylation

carboxylic acids

boron catalysis<smiles>CC(N)c1cccc2ccccc12</smiles>

A $(0.5 \mathrm{mmol})$<smiles>c1cnc(N2CCNCC2)nc1</smiles>

C $(0.5 \mathrm{mmol})$<smiles>O=C(O)CCc1cccc(C(F)(F)F)c1</smiles>

B (2.3 equiv)

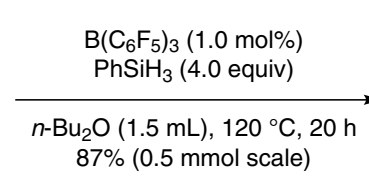

$87 \%$ (0.5 mmol scale)<smiles>CC(NCCCc1cccc(C(F)(F)F)c1)c1cccc2ccccc12</smiles><smiles>O=C(O)c1ccc2c(c1)OCO2</smiles>

D (2.3 equiv)

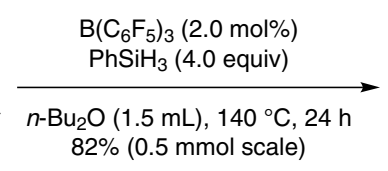<smiles>c1cnc(N2CCN(Cc3ccc4c(c3)OCO4)CC2)nc1</smiles>

Piribedil mp not reported<smiles>CC(C)(F)c1ccc(CN)cc1</smiles><smiles>O=C(O)c1cccc2ccccc12</smiles><smiles>CC(C)(C)c1ccc(CNC(=O)c2cccc3ccccc23)cc1</smiles>
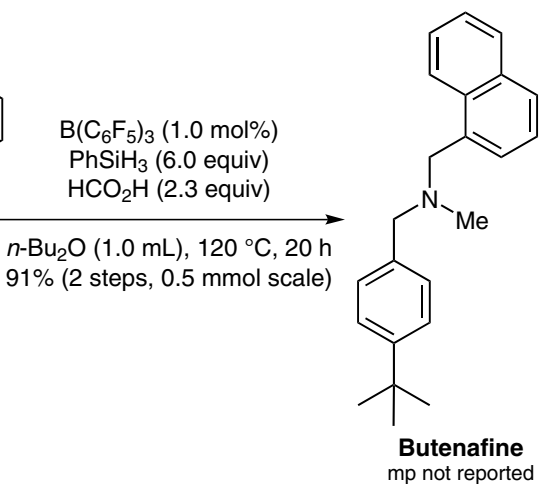

Significance: The boron-based catalyst

$\mathrm{B}\left(\mathrm{C}_{6} \mathrm{~F}_{5}\right)_{3}$, which can form a frustrated Lewis pair (FLP), catalyzes the $\mathrm{N}$-alkylation of amines using carboxylic acids in the presence of a silane reducing agent. The boron catalyst enables reductive carbon-nitrogen bond formation in preference to the reduction of the carboxylic acid. Only 1.0 mol\% of the boron catalyst is required. Twentyfour examples of the $\mathrm{N}$-methylation of various primary and secondary amines using formic acid and eighteen examples of the $\mathrm{N}$-alkylation of aniline with various carboxylic acids illustrate the scope of the reaction.
Comment: The utility of the $\mathrm{N}$-alkylation reaction is illustrated by the small-scale synthesis of three pharmaceutical agents. Cinacalcet (Sensipar ${ }^{\circledR}$, Mimpara $\left.{ }^{\circledR}\right)$ is a calcimimetic that is useful for the treatment of secondary hyperparathyroidism in patients with chronic kidney disease and hypercalcaemia in patients with parathyroid carcinoma. Piribedil (Pronoran ${ }^{\circledR}$ ) is a $D_{2}$ and $D_{3}$ receptor agonist that is used to treat Parkinson's disease.

Butenafine (Mentax ${ }^{\circledR}$ ) is a squalene epoxidase inhibitor that blocks the synthesis of ergosterol. It is used as a topical antifungal agent.

SYNFACTS Contributors: Philip Kocienski

Synfacts 2015, 11(11), $1121 \quad$ Published online: 19.10.2015

DOI: 10.1055/s-0035-1560694; Reg-No.: K05515SF 